BENHA VETERINARY MEDICAL JOURNAL, VOL. 33, No. 2:174-182, DECEMBER, 2017

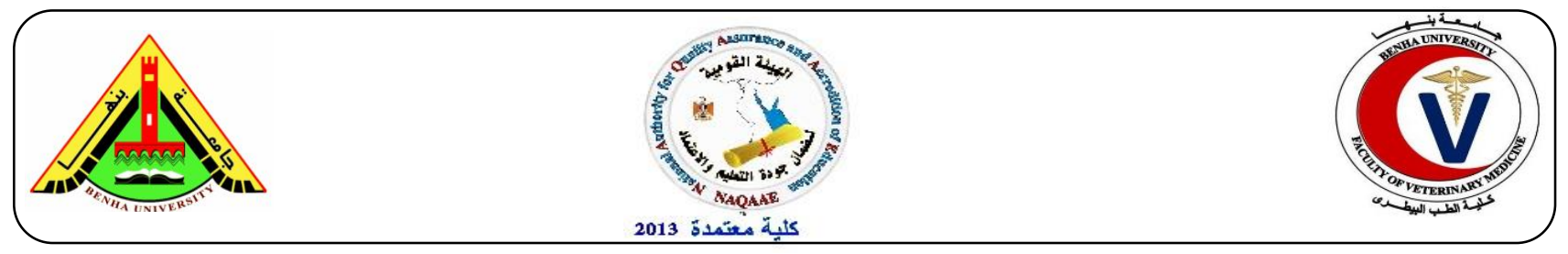

\title{
Evaluating humoral immune response of sheep vaccinated with inactivated RVF virus vaccine using oil nanoparticles adjuvant in comparison with aluminum hydroxide gel
}

\author{
El-Bagoury, G.F. ${ }^{1}$, El-Habbaa, A.S. ${ }^{1}$, Ibrahim, A.M. ${ }^{2}$ and Noha, E.E. Yousef ${ }^{2}$
}

${ }^{1}$ Departments of virology, Faculty of Veterinary Medicine, Benha University, Egypt, ${ }^{2}$ Veterinary Serum and Vaccine Research Institute, Abbassia, Cairo.

\section{A B S T R A C T}

In the present study an inactivated tissue culture adapted RVF virus vaccine was prepared using Montanide oil IMS 1313 nanoparticles as adjuvant then evaluated in sheep in comparison to the local RVF virus vaccine with aluminum hydroxide gel adjuvant using serum neutralization test (SNT) and Enzyme Linked Immuno-Sorbent Assay (ELISA). The prepared vaccine was sterile and safe inducing no systemic or local clinical signs in sheep. Results indicated that the prepared nanoparticles oil based vaccine induced a protective neutralizing serum antibody titer from the $2^{\text {nd }}$ week post vaccination (WPV), reached the highest level at the $3^{\text {rd }}$ month post vaccination (MPV) and persisted in protective level until the for $9^{\text {th }}$ MPV, while aluminum hydroxide gel based vaccine appeared in protective level at $2^{\text {nd }} \mathrm{WPV}$, reached the highest level at the $2^{\text {nd }}$ MPV and persisted in protective level till the $7^{\text {th }}$ MPV. These results were confirmed by using ELISA. These results demonstrated the potentiality of the prepared nanoparticles oil based vaccine compared to the locally produced aluminum hydroxide gel based vaccine reflected by greater immunogenicity and longer duration of immunity.

Key Words: RVF virus vaccines, Adjuvants, Sheep, SNT, ELISA.

\section{INTRODUCTION}

Rift Valley fever (RVF) virus, a Phlebovirus from the family Bunyaviridae, which is potentially transmitted by many different species of insect vectors that have a wide global distribution (Gubler, 2002). Periodic RVF outbreaks in livestock (goats, sheep, cattle, and camels) and acute febrile illness with hemorrhagic syndrome in humans have been reported widely throughout south and central Africa, from Kenya westward into Nigeria, Niger, Burkina Faso, Senegal,
Mauritania and northward into Egypt (Diallo et al., 2005).

To limit spread of the disease, veterinary vaccines are the first line of defense. Extensive work has been carried out to produce safe and efficient vaccines against RVF (Kamal, 2011). A trial for preparing a potent and safe inactivated vaccine to be used for controlling the spreading of the disease was attempted (Abd El Samea et al., 1994). In Egypt, inactivated RVF virus vaccine was 
produced with alum hydroxide gel adjuvant (El-Nimr, 1980 and Eman, 1995). The development of new vaccines focuses on the use of new adjuvants for increasing the effectiveness of various vaccines. For a long time, oil adjuvants based on incomplete Freund's adjuvant played an important role in commercial veterinary vaccines. However; the mineral oil used caused various local postvaccination reactions in vaccinated individuals (Vanselow, 1987). After replacing mineral oils with metabolisable natural oils (soya, sesame, olive, etc.) some local

\section{MATERIALS AND METHODS}

\subsection{Rift Valley Fever (RVF) Virus:}

RVF virus ZH501 strain propagated in Baby Hamster Kidney $\left(\mathrm{BHK}_{21}\right)$ cells at a final titer $10^{7.5} \operatorname{TCID}_{50} / \mathrm{ml}$, was obtained from RVF vaccine research department, Veterinary Serum and Vaccine Research Institute (VSVRI), Abbassia, Cairo. It was used in vaccine preparation and as a reference infective RVF virus for serum neutralization test (SNT). It was kept at $70^{\circ} \mathrm{C}$.

\subsection{Baby Hamster Kidney (BHK21) Cell culture:}

It was obtained from RVF vaccine research department, VSVRI, Abbasia, Cairo. It was grown and maintained according to (Macpherson and Stocker, 1962). It was used for propagation and titration of RVF virus and also used for SNT.

\subsection{Experimental Sheep:}

A total number of 14 adult susceptible sheep local breed of about $35-50 \mathrm{~kg}$ body weight, clinically healthy and were not vaccinated against RVF. The sheep were tested to be free from antibodies against RVF virus before the experimental work using SNT and were used for evaluation of the immune response of the inactivated Montanide oil IMS 1313 VG NP based reactions were eliminated (Reynolds et al., 1980). Now aluminum hydroxide is the substance most frequently used as adjuvant in veterinary medicine (Clements and Griffiths, 2002) although its potentiating effect fails to reach in general the level of oil adjuvants.

The present study was designed to assess the humoral immune response of Montanide oil IMS 1313 VG NP based vaccine in vaccinated sheep in comparison to the locally produced aluminum hydroxide gel based vaccine.

vaccine and the locally produced aluminum hydroxide gel based vaccine.

\subsection{Local inactivated RVF virus vaccine with aluminum hydroxide gel adjuvant:}

The inactivated RVF virus vaccine with aluminum hydroxide gel adjuvant is a locally prepared vaccine supplied by RVF vaccine research department, VSVRI, Abbassia, Cairo.

\subsection{Formulation of the inactivated RVF virus} Vaccine with IMS 1313 oil adjuvant:

RVF virus strain (ZH501) was inoculated in BHK-21 cell cultures. The cultures were incubated at $37^{\circ} \mathrm{C}$ and examined daily for cytopathic effect (CPE). After appearance of CPE in 50-70\% of the cell sheet, the tissue culture flask was freezed in freezer at $-20^{\circ} \mathrm{C}$ then thawed for 3 successive cycles for cell destruction and virus release. Virus harvest was centrifuged at $1500 \mathrm{rpm}$ for 30 minutes to remove cell debris; the clear supernatant fluid was collected aseptically and was kept at $-80^{\circ} \mathrm{C}$ then subjected to infectivity titration on $\mathrm{BHK}_{21}$ cell line (OIE, 2016). The harvested virus had a titer of $10^{8} \mathrm{TCID}_{50} / \mathrm{ml}$ (Reed and Muench, 1938), was inactivated by Binary Ethyleneimine (BEI), (Black burn and Besselaar, 1991). The vaccine was formulated according to the technical bulletin 
of Montanide oil IMS 1313 VG NP prescribed by Seppic, France. A total weight of 50 gram inactivated virus suspension was diluted in 50 gram of the oil (weight/ weight).

\subsection{In process control:}

\subsubsection{Checking the inactivation process:}

The inactivated virus suspension was assessed for complete inactivation by two passages of the inactivated virus in $\mathrm{BHK}_{-21}$ cell culture (OIE, 2014). No evidence of presence of any residual infectious virus was observed on inoculated cell culture.

\subsubsection{Sterility and safety evaluation of the} prepared vaccine:

Montanide oil IMS 1313 VG NP based vaccine was assessed for sterility using thioglycollate and soybean casein digest medium. It was assessed for safety by injection of $2 \mathrm{ml}(2 \mathrm{X})$ of the vaccine in sheep by subcutaneous (S/C) route, (OIE, 2016). The prepared vaccine was free from aerobic and anaerobic bacteria and fungi. It was also safe indicated by absence of local and systemic reactions on inoculated sheep with no rise in body temperature.

\subsection{Experimental design}

Fourteen susceptible local breed sheep (4-6 months old), healthy, clinically normal, and free from antibodies for RVF virus were used for evaluation of the humeral immune response of Montanide oil IMS 1313 VG NP based vaccine in vaccinated sheep in comparison to the locally produced aluminum hydroxide gel based vaccine, as follow:

Group 1: Six animals, each vaccinated subcutaneously $(\mathrm{S} / \mathrm{C})$ with $1 \mathrm{ml}$ of inactivated RVF virus vaccine with Montanide oil IMS 1313 VG NP.

Group 2: Six animals, each vaccinated subcutaneously $(\mathrm{S} / \mathrm{C})$ with $1 \mathrm{ml}$ of inactivated RVF virus vaccine with aluminium hydroxide gel.
Group 3: Two animals kept as non-vaccinated (control negative)

\subsection{Serum neutralization test (SNT):}

This test was used to detect the specific neutralizing antibodies against RVF virus in the serum samples of vaccinated sheep according to method of constant serumvirus dilution procedure (Walker, 1975). The serum-neutralizing index was calculated according to Reed and Muench (1938).

\subsection{Enzyme Linked Immunosorbent Assay} (ELISA):

Indirect method of ELISA technique was performed according to Voller et al., (1976) to estimate the specific antibodies against RVF virus in the serum samples of vaccinated sheep.

\section{RESULTS:}

Humoral immune response of sheep to nanoparticles Montanide oil IMS 1313 VG NP based vaccine was assessed in comparison to the locally produced aluminum hydroxide gel based vaccine using SNT and ELISA.

Results indicated that the Montanide oil IMS 1313 VG NP based vaccine induced a protective neutralizing serum antibody titer from the $2^{\text {nd }}$ week post vaccination (WPV), reached the highest level at the $3^{\text {rd }}$ month post vaccination (MPV) and persisted in protective level for $9^{\text {th }}$ MPV then declined to a nonprotective level while aluminum hydroxide gel based vaccine appeared in protective level at $2^{\text {nd }}$ WPV reached the highest level at the $2^{\text {nd }}$ MPV (Protective neutralizing index is 1.6 according to Randall et al., 1964). Serum neutralizing antibody titer persisted in protective level till the $7^{\text {th }}$ MPV then declined to a non-protective level, as shown in table (1) and Figure (1). Results of ELISA correlated with that obtained by SNT, as shown in table (2) and figure (2). 
Table (1): Mean serum antibody titers in sera of sheep vaccinated with inactivated RVF vaccine using SNT:

\begin{tabular}{|c|c|c|c|c|c|c|c|c|c|c|c|c|c|c|c|c|}
\hline \multirow{3}{*}{$\begin{array}{l}\text { Animal } \\
\text { group }\end{array}$} & \multicolumn{16}{|c|}{ Mean neutralizing indices at different period post vaccination } \\
\hline & \multirow{2}{*}{$\begin{array}{c}\text { Before } \\
\text { vaccination }\end{array}$} & \multicolumn{4}{|c|}{ Weeks post vaccination } & \multicolumn{11}{|c|}{ Months post vaccination } \\
\hline & & 1 st & 2nd & $3 \mathrm{rd}$ & 4th & $2^{\text {nd }}$ & $3 \mathrm{rd}$ & 4th & 5 th & 6th & 7 th & 8th & 9th & 10th & 11th & 12th \\
\hline G 1 & 0.61 & 1.53 & 1.81 & 1.94 & 2.24 & 2.59 & 2.94 & 3.49 & 3.06 & 2.91 & 2.78 & 2.31 & 2.02 & 1.91 & 1.78 & 1.53 \\
\hline${ }^{* * *} \mathrm{G} 2$ & 0.53 & 0.91 & 1.62 & 1.96 & 2.22 & 2.61 & 2.34 & 2.08 & 1.93 & 1.72 & 1.51 & 1.22 & 0.94 & 0.72 & 0.63 & 0.49 \\
\hline${ }^{* * *} \mathrm{G} 3$ & 0.42 & 0.47 & 0.41 & 0.38 & 0.43 & 0.46 & 0.39 & 0.42 & 0.38 & 0.39 & 0.41 & 0.43 & 0.40 & 0.37 & 0.39 & 0.39 \\
\hline
\end{tabular}

*Group 1: Sheep vaccinated with inactivatedRVF vaccinebased onMontanide oil IMS 1313 VG NPR.

${ }^{* *}$ Group 2: Sheep vaccinated with inactivatedRVF vaccinebased onaluminium hydroxide gel.

*** Group 3: Sheep non-vaccinated kept as control negative.

Protective neutralizing index is (1.6) according to Randall et al. (1964). 
Table (2): Mean antibody levels in sera of sheep vaccinated with inactivated RVF vaccine using ELISA:

\begin{tabular}{|c|c|c|c|c|c|c|c|c|c|c|c|c|c|c|c|c|}
\hline \multirow{3}{*}{$\begin{array}{l}\text { Anjmal } \\
\text { group }\end{array}$} & \multicolumn{16}{|c|}{ Mean values of ELISA optical density indices at different period post vaccination } \\
\hline & \multirow{2}{*}{$\begin{array}{c}\text { Before } \\
\text { vaccination }\end{array}$} & \multicolumn{4}{|c|}{ Weeks post vaccination } & \multicolumn{11}{|c|}{ Months post vaccination } \\
\hline & & 1 st & 2nd & $3^{\text {rd }}$ & 4th & $2^{\text {nd }}$ & $3^{\text {rd }}$ & 4th & 5 th & 6th & 7 th & 8th & 9th & 10th & 11th & 12th \\
\hline$\stackrel{0}{\mathrm{G}^{1}}$ & 0.053 & 0.243 & 0.259 & 0.272 & 0.296 & 0.312 & 0.329 & 0.346 & 0.328 & 0.306 & 0.297 & 0.283 & 0.274 & 0.261 & 0.252 & 0.242 \\
\hline$\stackrel{\mathrm{u}}{\mathrm{G}} 2$ & 0.049 & 0.226 & 0.246 & 0.272 & 0.293 & 0.318 & 0.296 & 0.278 & 0.262 & 0.251 & 0.242 & 0.235 & 0.213 & 0.198 & 0.181 & 0.143 \\
\hline $\mathrm{G}_{3}$ & 0.041 & 0.047 & 0.043 & 0.038 & 0.037 & 0.041 & 0.039 & 0.042 & 0.045 & 0.047 & 0.041 & 0.037 & 0.039 & 0.043 & 0.041 & 0.038 \\
\hline
\end{tabular}

1: Sheep vaccinated with inactivatedRVF vaccinebased onMontanide oil IMS 1313 VG NPR.

** Group 2: Sheep vaccinated with inactivatedRVF vaccinebased onaluminum hydroxide gel.

${ }^{* * *}$ Group 3: Sheep non-vaccinated kept as control negative. 

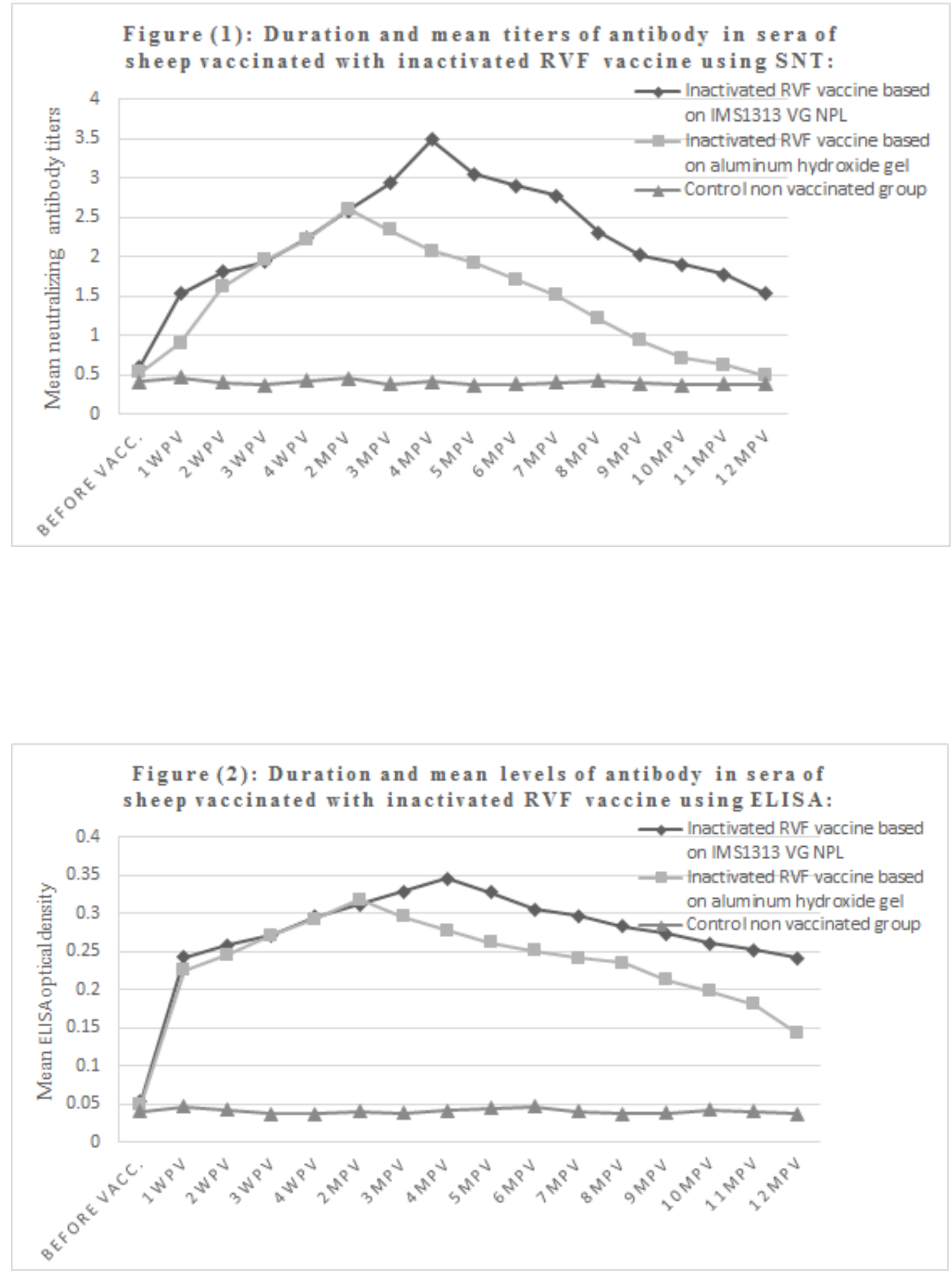


\section{DISCUSSION:}

Often vaccinologists search and aim to improve vaccines to overcome the obstacles which may face the older vaccines such as the unsafety or the low induced immunity. The use of adjuvant plays the greater role in this field. To overcome the distinct short comings of aluminum hydroxide gel vaccine like short duration and the need for one or more booster doses to maintain an adequate level of specific antibodies, several trials were conducted to switch to oil formulations as pea nut oil, nigella sativa oil and paraffin oil (Marcoss et al., 1998 and Ibrahim, 2002). The present study is a trial to improve the immunogenicity of the locally produced inactivated RVF virus vaccine using Montanide oil IMS 1313 VG NPR.

Numerous studies examined the immunoenhancing effects of Montanide oil IMS 1313 VG nanoparticle adjuvant vaccine formulations, and demonstrated encouraging efficacy against many pressing infectious threats (Sonia 2003; Jang et al., 2011 and Naggar et al., 2017).

Results revealed that the prepared vaccine formula was free from foreign contaminants (aerobic and anaerobic bacteria; fungi) and safe in vaccinated animals where such animals remained healthy all over the experimental period without local reaction at the site of inoculation. These observations agree with the recommendations of USA-CFR (1987).

Evaluation of humeral immune response in vaccinated sheep studied by SNT showed that mean neutralizing index (NI) in sera from vaccinated sheep started to rise from 1st WPV and increased to the protective level at 2nd WPV in both the inactivated Montanide oil IMS 1313 VG NPR based vaccine and the locally prepared RVF virus vaccines with aluminum hydroxide gel adjuvant (Protective neutralizing index is 1.6 according to Randall et al., (1964). These results agree with those of Eman (1995),
El Nimr (1980) and Gihan (1990) who recorded that the protective NI level obtained by the inactivated RVF virus vaccines was 2 WPV.

The mean neutralizing indices in sera of sheep vaccinated with the inactivated Montanide oil IMS 1313 VG NPR based vaccine increased gradually till reached the peak (2.9) at the $3^{\text {rd }}$ MPV then the level decreased to be (1.7) at the $9^{\text {th }}$ MPV then declined to a non-protective level (below 1.6) .

In sera of sheep vaccinated with the inactivated aluminum hydroxide gel based vaccine, the mean neutralizing indices reached the peak (2.6) at the $2^{\text {nd }}$ MPV then the level decreased to be (1.7) at the $7^{\text {th }}$ MPV and then decline to a non-protective level (below 1.6). These results come in agreement with those of Patil et al., (2002) and Lyer et al. (2000) who recorded that the oil Foot and Mouth Disease virus vaccine, elicited superior immune response than the aluminum hydroxide gel vaccine and the development of immune response was quicker.

The result of ELISA was correlated with that obtained by SNT. These results come in agreement with those of Paweska et al., (2005); Ali et al., (2012) and Catherine et al., (2009) who used ELISA for detection of IgG instead of SNT. They demonstrated that ELISA is a guide test, which is safe and useful for monitoring of immune response after vaccination.

In conclusion, results gave the priority to the prepared inactivated Montanide oil IMS 1313 VG NPR based RVF virus vaccine over the locally produced inactivated aluminum hydroxide gel vaccine beside that RVF virus vaccine with Montanide oil IMS 1313 VG NPR adjuvant induced immunological response with longer duration. These adjuvants are patent contain its own surfactant which enable an easy manufacturing of vaccines by mixing the aqueous medium into the montanide oil at room temperature. Application of such vaccine will be 
added value to improve the locally produced

\section{REFERENCES:}

Abd El Samea, M.M.; Elian, K.; Gihan, K.M. 1994. The effect of Rift Valley Fever and sheep pox vaccines on the immune response of sheep. J. Egypt. Vet. Med. Ass. 2:129-136.

Ali, S.M.; Abdel Baky, M.H.; Al-Blowi, M.H.2012. Comparison Between two Commercial Kits used for Detection of Anti-Rift Valley Fever Antibodies in Sheep Vaccinated with Smithburn Vaccine, Short Communications. Journal of Advanced Veterinary Research, Vol 2, No. (3), pp. 208 210.

Blackburn, N.K.; Besselaar, T.G. 1991. A study of the effect of chemical inactivants on the epitopes of Rift Valley fever virus glycoproteins using monoclonal antibodies. J. Virol. Methods; 33:367-374.

Catherine, C.; Agne`s, B.; Renaud, L.; Ce' dric, D.; Jacques, F.; Michele, B.; Dominique, M.; Emmanuel, A. 2009. Evaluation of a commercial competitive ELISA for the detection of antibodies to Rift Valley fever virus in sera of domestic ruminants in France. Preventive Veterinary Medicine Journal, 90: 146-149.

Clements, C.J.; Griffiths, E. 2002. The global impact of vaccines containing aluminium adjuvants. Vaccine; 20: 24-33.

Diallo, M.; Nabeth, P.; Ba, K.; Sall, A.; Ba, Y.; Mondo, M.; Girault, L.; Abdalahi, M.; Mathiot, C. 2005. Mosquito vectors of the 1998-1999 outbreak of Rift Valley Fever and other arboviruses (Bagaza, anar,
RVF virus vaccine.

Wesselsbron and West Nile) in Mauritania and Senegal. Med. Vet. Entomol. 19, 119-126.

El-Nimr, M.M. 1980. Studies on the inactivated vaccine against RVF. Ph. D. Thesis (Microbiology). Fac. Vet. Med Egypt: Assiut University.

Eman, M.S.S. 1995. Studies on RVF vaccine inactivated with Binary.Ph. D. Vet. Sc. thesis Microbiology, Fac. of Vet. Med. Cairo - Univ.

Gihan, K.M. 1990. Studies on Rift Valley Fever among animals in Egypt.

Ph.D. Thesis, Inf. Dis., Fac. of Vet. Med., Zagazig Univ., Egypt.

Gubler, D.J. 2002. The global emergence/resurgence of arboviral diseases as public health problems. Arch. Med. Res. 33,330-342.

Ibrahim, A.M. 2002. Improvement and evaluation of inactivated Rift Valley Fever vaccine. Ph.D. Thesis, Infectious Diseases, Fac. Vet. Med., Moshtohor, Zagazig Univ.

Jang, S.I.; Lillehoj, H.S.; Lee, S.H.; Lee, K.W.; Lillehoj, E.P.; Bertrand, F.; Dupuis, L.; Deville, S. 2011. Montanide IMS 1313 N VG PR nanoparticle adjuvant enhances antigen-specific immune responses to profilin following mucosal vaccination against Eimeria acervuline. Vet. Parasitol.; 182(2-4):163-70.

Kamal, S.K. 2011. Observations on rift valley fever virus and vaccines in Egypt. Virol. J. 8: 532-540.

Mackpherson, L.A.; Stocker, M.G.P. 1962. Polyoma transformation of hamster cell colonies; An investigation of genetic factors affecting cell competence. Virology, 16: 147. 
Lyer, A.V.; Ghosh, S.; Singh, S.N.; Deshmukh, R.A. 2000. Evaluation of three "ready to formulate" oil adjuvants for FMD disease vaccine production. Vaccine; 19 (9-10): 1097105.

Marcoss, T.N.; Lily, S. Salama; Elian, A. Aly 1998. Studies of different adjuvants on the immune response of sheep to Rift Valley fever inactivated vaccine. Vet. Med. J., Giza, 64 (4B): 719-727.

Naggar, H.M.E.; Madkour, M.S.; Hussein, H.A. 2017. Preparation of mucosal nanoparticles and polymer-based inactivated vaccine for Newcastle disease and H9N2 AI viruses. Veterinary World, 10(2), 187-193.

Office international de epizootics (OIE), 2014. OIE Terrestrial Manual. Chapter 2.1.14. Rift Valley Fever, Available from: http://www.oie.int/wahis2devt.oie.int/fileadmin/Home/fr/Health. ../2.01.14_RVF.pdf

OIE, 2016. OIE Terrestrial Manual. Chapter 2.1.18. Rift Valley fever. Available from:

http://www.oie.int/en/internationalstandard-setting/terrestrialmanual/access-online

Paweska, J.T.; Mortimer, E.; Leman, P.A.; Swanepoel, R. 2005. An Inhibition enzyme - linked immunosorbent asseny for the detection of antibody to Rift valley fever virus in humans, domestic and wild kuminauts. J. Virol. Methods, 127: 10-18.

Patil, P.K; Bayry, J.; Ramkrishna. C.; Hygar, B.; Misra, L.D.; Natarajan, C. 2002. Immune response of goat against FMD quadrivalent vaccine: Comparision of double oil emulsion and alluminium hydroxide gel. Vaccine; 20 (21-22) :2781-2789.

Randall, R.; Binn, L.N.; Harison, V.R. 1964. Immunization against Rift Valley Fever virus. Studies on the immunogenicity of lyophilized formalin inactivated vaccine. J. Imm., 93 (2): 293-299.

Reed, L.J.; Muench, H. 1938. A simple method for estimating 50 percent end point. Am. J. Hyg., 27: 493-497.

Reynolds, J.A.; Harrington, D.G.; Crabbs, C.L.; Peters, C.J., Di Luzio, N.M. 1980. Adjuvant activity of a novel metabolisable lipid emulsion with inactivated viral vaccines. Infect Immun; 28: 937-943.

Sonia, A.M. 2003. Comparative studies on immune response of FMD and RVF combined vaccine containing IMS 1313 oil adjuvant. M.V.Sc. Thesis, Microb. Fac. Vet. Med., Alex. University.

USA-CFR 1987. Code of Federal Regulation; United States of America.

Vanselow, B.A. 1987. The application of adjuvants to veterinary medicine. Vet Bull. 57:881-96.

Voller, A.; Bidwell, D.; Bartlett, A. 1976. Microplate enzyme immunoassay for the immunodignosis of virus infection. Am. Soc. for Micro., 506-512.

Walker, J.S. 1975. Rift Valley Fever foreign animal disease. Their prevention, diagnosis and control. Committee of foreign animal disease of the United States. Animal Health Assoc.: 209 221 